\title{
Knowledge, Attitudes, and Behavior of Larva Monitoring Interpreter (Jumantik) Cadre as Efforts to Prevent Dengue Cases
}

\author{
Tjitrowati Dja'afar, Dedi Mahyudin Syam*iD, Andi Bungawati, Ros Arianty \\ Department of Sanitation, Poltekkes Kemenkes Palu, Palu, Indonesia
}

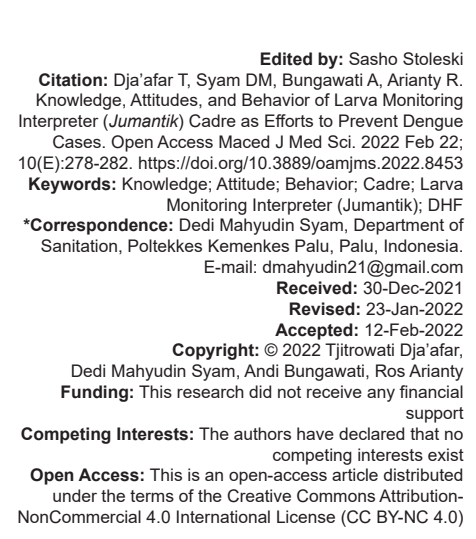

\section{Introduction}

Fever dengue still is the problem of health public primary in the whole area of the tropical and sub-tropical in the world [1]. Dengue hemorrhagic fever (DHF) is one of the infectious diseases and a major public health problem in Indonesia. DHF is a disease caused by the dengue virus belonging to the Arthropod-Borne virus and genus Flavivirus. According to the WHO data, Asia Pacific bear $75 \%$ of the burden of dengue in the world between 2004-2010, while Indonesia reported as the second country with the largest dengue cases among the 30 countries endemic region [2]. Dengue fever (DB) is a viral infection that is transmitted through the bite of Aedes aegypti and Aedes albopictus mosquitoes [3], [4]. Data from around the world show that Asia ranks first in the number of DHF sufferers each year. Meanwhile, starting from 1968 until 2009, the World Health Organization (WHO) notes state of Indonesia as the country with the highest dengue cases in Southeast Asia [5].
DHF cases reported in 2019 were 138,127 cases. This number increased compared to 2018 of 65,602 cases. Deaths due to DHF in 2019 also increased compared to 2018 from 467 to 919 deaths. Illness and death can be described using the incidence rate (IR) indicator per 100,000 population, 2018 IR 24.75, and 2019 IR 51.48. Cases of DHF in the Central Sulawesi Province in 2019 showed an IR of $63.75 / 100,000$ people died or a Case Fatality Rate of $0.87 \%$ [6]. Efforts to prevent and control DHF in Palu City are still inadequate, from the results of a survey that has been carried out by officers, it shows that community participation in the Eradication of Mosquito Nests Pemberantasan Sarang Nyamuk (PSN), especially in closing, draining and burying (3M) activities, is still lacking. Based on available data, the implementation of $3 \mathrm{M}$ in Palu City is closing $5.2 \%$ inside the house, and $2.8 \%$ outside the house, draining $58 \%$ doing it inside the house and $20.7 \%$ outside the house, and burying $1.7 \%$ doing inside the house and $0.3 \%$ outside the house. The lack of community participation in the implementation of $3 \mathrm{M}$ causes the density of $A$. aegypti 
larvae to be high (81.1\%). The effort made by the Palu City Health Office to reduce the incidence of DHF is the implementation of focus fogging. The implementation of focus fogging from January to December 2007 has been carried out in Palu City as many as 79 times and spread across four sub-districts throughout Palu City, but did not give satisfactory results on the incidence of DHF [7].

According to Kamil (2010), knowledge can be increased through training. The basic concept of the training is to provide knowledge material about dengue disease and dengue-transmitting mosquitoes and provide information and motivation so that later good behavior can be created so that they are able to carry out PSN DHF [8]. According to Lawrence and Marshall. Green, there are three behavioral determinants for a person, namely, predisposing factors (predisposing factors), enabling factors (supporting factors) and reinforcing factors (pushing factors). Predisposing factors include knowledge, attitudes, beliefs, values, and perceptions, regarding the motivation of a person or group to act. Enabling factors include the skills and resources necessary to perform health behaviors and other variables included in the supporting factors include cost, distance, and availability of transportation. Reinforcing factors include attitudes and behaviors of health workers, community leaders, religious leaders, parents, or other officers who constitute the reference group of people's behavior [9]. Jumantik was a trained local community member as a form of movement or active participation of tackling the dengue disease [10].

The purpose of the study was to analyze the knowledge, attitudes, and behavior of larva monitoring interpreters (Jumanatik) before and after being given health education in reducing dengue cases.

\section{Methods}

This type of research is a quasi-experimental, with one group pre- and post-test design. This research was conducted in Palu City, Central Sulawesi Province and Pasang Kayu Regency, West Sulawesi Province. Implementation time is May-September 2021. The population in this study is larva monitoring interpreter (Jumantik) in the city of Palu, Central Sulawesi Province and Pasang Kayu Regency, Mamuju Province. The sampling technique was purposive, while the calculation of the sample size in this study was carried out based on the calculation of the sample size according to Lemeshow et al, (1997) [11], the sample size was 98 Jumantik people.

Study instrument to facilitate the interview, a set of previously validated and tested questionnaires was used. Informed consent was taken from all respondents and confidentiality was guaranteed throughout the study. Each individual was given a total score based on the variables expressed in the number (percentage) for data on age, gender, education, occupation. Data were analyzed using SPSS 16 with paired t-test dependent.

\section{Results}

The characteristics of the respondents are shown in Table 1, there are more women (57.7\%) than men $(42.3 \%)$, the age group $36-40$ years the most $(21.4 \%)$ and $56-60$ years the least (2, 82\%), the most education is high school $(48.0 \%)$ and the least is masters $(3.1 \%)$, and the most occupations as housewives $(25.5 \%)$ and the least is farmers $(9.2 \%)$

Table 1: Characteristics of Jumantik Cadres

\begin{tabular}{lll}
\hline Variable & $\mathrm{N}$ & $\%$ \\
\hline Gender & 42 & \\
Male & 46 & 42.9 \\
Female & 56.1 \\
Age (years old) & 11 & \\
$20-25$ & 12 & 11.3 \\
$26-30$ & 17 & 12.3 \\
$31-35$ & 21 & 17.3 \\
$36-40$ & 10 & 21.4 \\
$41-45$ & 12 & 10.2 \\
$46-50$ & 6 & 12.2 \\
$51-55$ & 2 & 6.1 \\
$56-60$ & 7 & 2.1 \\
$61-65$ & & 7.1 \\
Education & 7 & \\
ElementaryEducation & 6 & 7.1 \\
Juniorhighschool & 47 & 6.1 \\
SeniorHighSchool & 12 & 48.0 \\
Diploma & 23 & 12.3 \\
Bachelor & 3 & 23.4 \\
Magister & & 3.1 \\
Work & 16 & 16.3 \\
Civilservant & 15 & 15.3 \\
Trader & 9 & 9.2 \\
Farmer & 18 & 18.4 \\
Laborer & 11 & 11.2 \\
Fisherman & 29 & 29.6 \\
Housewife & 98 & $\%$ \\
Total & & \\
\hline
\end{tabular}

Table 2 shows the results that the knowledge variable on how to prevent DHF increased with the highest value from the pre-test (20.10) and posttest (51.77) meaning an increase of $32.3 \%$, while the smallest increase was knowledge about the spread of DHF with a pre-test value (12.9) and post-test (14.2) meaning an increase of $1.3 \%$.

Table 3 shows that the attitude variable with the highest increase in value was about efforts to control DHF with a pre-test value (9.4) and post-test $(48.2 \%)$ meaning an increase of $38.8 \%$, while the smallest increase was the attitude of responsibility for disease management. DHF with a pre-test score (53.32) and post-test (53.50) means an increase of $0.18 \%$. However, before the counseling intervention was carried out, these results showed that many respondents knew about the responsibility for controlling DHF.

Table 4 shows that the behavioral variable with the highest increase in the value of larvae control 
Table 2: Average and Percentage of Knowledge of Jumantik Cadres

\begin{tabular}{|c|c|c|c|}
\hline Knowledge & MeanScore & $\%$ & p-value \\
\hline \multicolumn{4}{|c|}{ Causes of dengue disease } \\
\hline Pre-test & 57.10 & 58.3 & \multirow[t]{2}{*}{0.002} \\
\hline Post-test & 59.50 & 60.7 & \\
\hline \multicolumn{4}{|c|}{ Symptoms of DHF sufferers } \\
\hline Pre-test & 57.08 & 58.2 & \multirow[t]{2}{*}{0.002} \\
\hline Post-test & 59.51 & 60.7 & \\
\hline \multicolumn{4}{|c|}{ The impact of the danger of dengue disease } \\
\hline Pre-test & 46.25 & 47.2 & \multirow[t]{2}{*}{0.010} \\
\hline Post-test & 49.31 & 50.3 & \\
\hline \multicolumn{4}{|c|}{ Spread of disease } \\
\hline Pre-test & 12.67 & 12.9 & \multirow[t]{2}{*}{0.003} \\
\hline Post-test & 13.91 & 14.2 & \\
\hline \multicolumn{4}{|c|}{ Uses of Abate } \\
\hline Pre-test & 8.01 & 8.2 & \multirow[t]{2}{*}{0.000} \\
\hline Post-test & 31.11 & 31.7 & \\
\hline \multicolumn{4}{|c|}{ Potential places for dengue transmission } \\
\hline Pre-test & 7.41 & 7.6 & \multirow[t]{2}{*}{0.000} \\
\hline Post-test & 38.36 & 39.1 & \\
\hline \multicolumn{4}{|c|}{ How to prevent dengue } \\
\hline Pre-test & 20.10 & 20.5 & \multirow[t]{2}{*}{0.000} \\
\hline Post-test & 51.7 & 52.8 & \\
\hline \multicolumn{4}{|c|}{ DHF eradicate on health center program } \\
\hline Pre-test & 13.16 & 13.4 & \multirow[t]{2}{*}{0.000} \\
\hline Post-test & 44.00 & 44.9 & \\
\hline
\end{tabular}

with the pre-test (4.75) and post-test (37.78) means an increase of $33.0 \%$, while the smallest increase is the behavior of draining the water tank with the pretest value. Test (26.87) and post-test (35.83) means an increase of $8.96 \%$.

Table 3: average and percentage of attitude and behavior of Jumantik Cadres

\begin{tabular}{llll}
\hline Attitude & Mean score & $\%$ & p-value \\
\hline Responsibilities of Dengue Fever & & & \\
$\quad$ Pre-test & 53.32 & 54.4 & 0.737 \\
$\quad$ Post-test & 53.50 & 54.6 & \\
DHF prevention efforts & & & \\
$\quad$ Pre-test & 9.25 & 9.4 & 0.000 \\
$\quad$ Post-test & 47.23 & 48.2 & \\
DHF prevention efforts & & & \\
$\quad$ Pre-test & 21.00 & 21.4 & 0.000 \\
$\quad$ Post-test & 55.00 & 56.1 & \\
Hanging clothes & & & \\
$\quad$ Pre-test & 22.04 & 22.5 & 0.000 \\
$\quad$ Post-test & 54.63 & 55.7 & \\
Larva monitoring & & & \\
$\quad$ Pre-test & 19.53 & 19.9 & 0.000 \\
$\quad$ Post-test & 55.15 & 56.3 & \\
The effectiveness of fogging in preventing DHF & & & \\
$\quad$ Pre-test & 23.93 & 24.4 & 0.000 \\
$\quad$ Post-test & 53.22 & 54.3 & \\
\hline
\end{tabular}

\section{Discussion}

The results of this study found that counseling to Jumantik Cadres about preventing DHF given to cadres was effective in increasing the knowledge of cadres. Providing information to increase knowledge so that it raises awareness and in the end someone will behave in accordance with that knowledge [12]. All indicators of knowledge variables ranging from how to prevent DHF increased with a pre-test value (20.10) post-test (51.77) an increase of $32.3 \%$, to knowledge about the spread of DHF with a pre-test value of $51.77 \%$. Test (12.9) and post-test (14.2) means an increase of $1.3 \%$, based on the results of the paired T-test all showed significant $p$ $=0.000-0.003$. This shows that the knowledge of the respondents has increased after receiving the counseling intervention. This is in line with the research of Sugiono in Sukoharjo Regency, Sustin et al. in Surabaya and Azhar et al. in Malang City [13], [14], [15].

Theoretically, it is explained that PSN DHF should be carried out routinely by involving the whole community including Jumantik and the head of RT [16]. The results show that the knowledge pre-test scores between Jumantik Cadres are different. This could be due to differences in information between cadres obtained before the training. This difference is in accordance with the theory which states that information can affect a person's knowledge [17], [18], [19]. For the prevention of $\mathrm{DB}$, it is hoped that the community will always be given increased knowledge [20], [21]. The results showed that from the Jumantic attitude assessment indicators, there was one indicator that did not significantly change the attitude value, namely, the attitude of responsibility for controlling DHF with $p=0.737$. While the other indicators all experienced significant changes in attitude values ranging from indicators of efforts to control dengue disease to the effectiveness of using fogging to prevent dengue with $p=0.000$. The improvement in the quality of this positive attitude indicates that the extension worker has succeeded in communicating with the respondent. Considering that attitude is a person's closed response to a particular stimulus or object that involves the opinion and emotion factor concerned [12], [22]

Table 4: Average and percentage of behavior of Jumantik Cadres

\begin{tabular}{llll}
\hline Behavior & Mean score & $\%$ & p-value \\
\hline Draining Tub of Water & & & \\
$\quad$ Pre-test & 26.87 & 27.4 & 0.002 \\
$\quad$ Post-test & 35.83 & 36.6 & \\
Use of water storage containers & 30.79 & 31.4 & 0.000 \\
$\quad$ Pre-test & 41.20 & 42.0 & \\
$\quad$ Post-test & & & \\
Using Abate & 21.09 & 21.5 & 0.000 \\
$\quad$ Pre-test & 41.20 & 42.0 & \\
$\quad$ Post-test & & & \\
Larva surveillance behavior & 4.75 & 4.8 & 0.000 \\
$\quad$ Pre-test & 37.78 & 38.6 & \\
$\quad$ Post-test & 4.67 & 4.8 & 0.000 \\
Behavior of storing clothes & 25.06 & 25.6 & \\
$\quad$ Pre-test & & & \\
$\quad$ Post-test & 11.20 & 11.4 & 0.002 \\
Use of personal protection against mosquito bites & 27.93 & 28.5 & \multirow{2}{*}{0.002} \\
$\quad$ Pre-test & & & \\
$\quad$ Post-test & 11.20 & 11.2 & \\
Waste management behavior & 34.47 & 35.2 & \\
$\quad$ Pre-test & & & \\
$\quad$ Post-test &
\end{tabular}

The increase in the attitude of Jumantik Cadres is also supported by the outreach method using leaflet media accompanied by pictures; this is in line with the research conducted by Smith Boonchutima et al. in Thailand [23]. The results of the analysis of the attitude value showed that there was a difference in the increase in the attitude value of Jumantik Cadres who were given health education, through the extension method. In the treatment group through the counseling method, the participants listened more and expressed their opinions about health problems related to DB and the prevention of DHF.

This study is in line with the results of research Charuai Suwanbamrung in Kanchanadit district in 
the province of Surat Thani, about $651 \mathrm{~km}$ South of Bangkok, capital of Thailand, which concluded that to improve knowledge and attitudes essential increase in community health education program [24]. The existence of differences in the level of the attitude shown by the Cadres Jumantik before and after extension is consistent with research Fatmawati against high school students in Surakarta where there are differences in attitudes about sexually transmitted diseases before and after health education intervention [25]. Overall, the results of the study show that the health education carried out can change the attitude of Jumantik Cadres regarding the prevention of DHF. In accordance with Notoatmodjo's opinion, health education can influence and invite other people, both individuals, groups, and communities to carry out healthy lives. Operationally is an activity to provide knowledge, attitudes, and practices of the community in maintaining and improving their own health [12]. A total of seven behavioral assessment indicators, all of which showed an increase in the pretest and post-test scores. The behavior with the highest increase in the value of larvae control with the pre-test (4.75) and post-test (37.78) means an increase of 33.0\% with a significant value of $p=0.000$, while the smallest increase is the behavior of draining the tub. Water with a pre-test value (26.87) and post-test (35.83) means an increase of $8.96 \%$ with a $p=0.002$.

The supervision behavior of larvae by Jumantik Cadres experienced the highest increase because in the counseling process, more emphasis was placed on larva control activities in their respective homes, because this was the main target to break the chain of transmission of DHF. From the results of the pre-test assessment, only $4.75 \%$ showed that before counseling efforts to control larvae by cadres were still lacking, but after counseling the results greatly increased to $37.78 \%$, this was influenced by a strong desire by cadres to prevent transmission of dengue disease in their neighborhood. This is in accordance with Notoatmojo's opinion that a behavior is influenced by the belief that the behavior will bring desired or unwanted results that are normative and motivates to act in accordance with expectations. These normative expectations form subjective norms within the individual. This is determined by past experiences and the experiences of people around and individuals regarding how difficult or easy it is to perform the behavior. Health behavior is largely determined by the presence or absence of health education that has been received [12].

The behavior of draining water tanks by Jumantik Cadres, when viewed from the increase value is only $8.96 \%$, but the pre-test value has reached $26.8 \%$ and the post-test reached $35.83 \%$, it shows that the behavior of draining the water tank before receiving counseling has shown a higher value compared to larval control behavior. This is because the Jumantik Cadres already has an understanding of the importance of cleaning the water tank as an effort to develop larvae.
Understanding the importance of cleaning water tanks as an effort to prevent DB, apart from being obtained from health workers, information is also obtained through radio and TV media. This is in accordance with the research of Faisal Shuaib et al. in parish Westmoreland, Jamaica [26], [27], [28]. The increased quality of DHF prevention behavior by Jumantik Cadres in both Palu city and Pasangkayu district was caused by the fast understanding when getting counseling materials and supported by the productive age of cadres $31-40$ years $(38.7 \%)$ and higher education levels from senior high school to senior high school. masters. This positive condition causes that it is still easy to provide knowledge about the movement to prevent the transmission of dengue disease.

\section{Conclusion}

Health education through counseling methods is effective in increasing the knowledge, attitudes, and behavior of Jumantik Cadres in preventing DHF. It is recommended that health workers provide more intensive counseling to Jumantik Cadres and the community in general so that the prevention of dengue transmission can be effective.

\section{Reference}

1. World Health Organization. Thresholds for the cost effectiveness of interventions: alternative approaches. Bull World Health Organ. 2015;93(2):118-24. https://doi.org/10.2471/BLT.14.138206 PMid:25883405

2. Pusdatin. Demam Berdarah Dengue. Jakarta: Pusdatin; 2018.

3. Egger JR, Ooi E, Kelly DW, Woolhouse ME, Davies R, Coleman PG. Reconstructing historical changes in the force of infection of dengue fever in Singapore: Implications for surveillance and control. Bull World Health Organ. 2008;86(3):187-96. https://doi.org/10.2471/blt.07.040170

PMid:18368205

4. Guha-sapir D, Schimmer B. Dengue fever: New paradigms for a changing epidemiology. Emerg Themes Epidemiol. 2005;2(1):1. https://doi.org/10.1186/1742-7622-2-1

PMid:15743532

5. Brahim R, Hasnawati, Anggraeni ND, dan Ismandari F. Demam Berdarah Dengue di Indonesia Tahun 1968-2009. Bul Jendela Epidemiol. 2010;2:1-14.

6. Kementerian Kesehatan RI. Profil Kesehatan Indonesia 2019. Jakarta; 2020. p. 189-91.

7. Dinas Kesehatan Kota Palu. Profil Kesehatan Kota Palu. Palu: Dinas Kesehatan Kota Palu; 2020.

8. Kamil. Model Pendidikan dan Pelatihan (Konsep dan Aplikasi), Alfabeta, Bandung. Jakarta: Alfabeta; 2010.

9. Green LW, Marshall K. Health Program Planning:An Educational and Ecological Approach. $4^{\text {th }}$ ed. New York : McGraw-Hill; 2005. 
10. Kementerian Kesehatan RI. Petunjuk Teknis Implementasi PSN 3M-Plus dengan Gerakan 1 Rumah 1 Jumantik. Jakarta: Kementerian Kesehatan RI; 2016

11. Lameshow S, Hosmer DW, Klar J, Lwanga S. Besar Sampe Dalam Penelitian Kesehatan. Jogjakarta: Gadjahmada University Press; 1997.

12. Notoatmodjo S. Promosi Kesehatan dan IImu Perilaku. Jakarta: PT Rineka Cipta; 2010.

13. Sugiono. Pengaruh pelatihan pencegahan Demam Berdarah Dengue Terhadap Tingkat Pengetahuan dan Sikap Siswa D SDN Wirogunan I Kartasuro Kabupaten Sukoharjo; 2012.

14. Sustin F, Andajani SA. The training of wiggler monitoring of primary school teacher and studentin surabaya to improve eradication of dengue hemorragic fever. Folio Med Indones. 2021;48(1):28-31.

15. Azhar NH, Zuhriyah L. Pemberdayaan Siswa Pemantau Jentik dengan Metode Manga Zone sebagai Salah satu Pencegahan Kasus demam Berdarah dengue Di Daerah kelurahan Sawo Jajar Kota Malang. FKUB. 2015;2(1):8-15.

16. Kemenkes RI. Petunjuk Teknis Pemberantasan Sarang Nyamuk (PSN) oleh Juru Pemantau Jentik (jumantik). Jakarta: Kementerian Kesehatan RI; 2012.

17. Budiman AR. Pengetahuan dan Sikap Dalam Penelitian Kesehatan. Jakarta: Salemba Medika; 2013.

18. Kazaura M. Knowledge, attitude and practices about dengue fever among adults living in Pwani Region, Tanzania in 2019 Afr Health Sci. 2020;20(4):1601-9. https://doi.org/10.4314/ahs. v20i4.12

PMid:34394220

19. Zulkifli A, Sidin Al, Nasrah N, Rahmah S, Fitri AU. Strengthening community-based surveillance cadre activeness through interpersonal communication and module development in Barru district. Open Access Maced J Med Sci. 2021;9:187-91.

20. Harapan H, Rajamoorthy $Y$, Anwar S, Bustamam A, Radiansyah A, Angraini P, et al. Knowledge, attitude, and practice regarding dengue virus infection among inhabitants of Aceh, Indonesia: A cross-sectional study. BMC Infect Dis. 2018;18(1):96. https://doi.org/10.1186/s12879-018-3006-z PMid:29486714

21. Mian N. Knowledge, attitude and practices regarding dengue fever in people of Lahore. Med Forum Mon. 2012;23(5):13-8.

22. Azwar S. Sikap Manusia Teori dan Pengukurannya. Yogyakarta: Pustaka Pelajar; 2011

23. Boonchutima S, Kachentawa K, Limpavithayakul M. Longitudinal study of Thai people media exposure, knowledge, and behavior on dengue fever prevention and control. J Infect Public Health. 2017;10(6):836-41. https://doi.org/10.1016/j.jiph.2017.01.016 PMid:28285970

24. Suwanbamrung C, Saengsuwan B, Sangmanee T. Knowledge, attitudes, and practices towards dengue prevention among primary school children with and without experience of previous dengue infection in southern Thailand. One Health. 2021;13:100275. https://doi.org/10.1016/j.onehlt.2021.100275 PMid:34159247

25. Fatmawati. Pengaruh Pendidikan Kesehatan tentang Penyakit Menular Seksual terhadap Perubahan Pengetahuan dan Sikap Siswa SMAN 8 Surakarta. Surakarta: Fak Kesehat Masyarakat, Surakarta; 2010.

26. Shuaib F, Todd D, Campbell-Stennett D, Ehiri J, Pauline E. Knowledge, attitudes and practices regarding dengue infection in Westmoreland, Jamaica. West Indian Med J. 2010;59(2):139-46.

PMid:21132094

27. Srinivasa S, Harish S, Patel RA, Bhavya G. Knowledge, attitude and practice regarding dengue infection among parents of children hospitalized for dengue fever. Int $\mathrm{J}$ Contemp Pediatr. 2018;22(1):893-7.

28. Nalongsack S, Yoshida Y, Morita S, Sosouphanh JS. Knowledge attitude and practice regarding dengue among people in Pakse, Laos. Nagoya J Med Sci. 2009;71(1-2):29-37.

PMid:19358473 